\title{
ヌードマウス移植可ヒト肺癌細胞を用いた 尿中フィブロネクチンの検討
}

\author{
Analysis of Urinary Fibronectin (UFN) using \\ Human Lung Cancer Cells Transplanted into Nude Mice
}

野中 誠・門倉光隆 - 谷尾 昇 - 山本 滋 - 高場利博

\begin{abstract}
要旨：血漿や結合組織など生体内に広く存在するフィブロネクチン $(\mathrm{FN})$ は癌患者尿中に多量 に出現し, この尿中FN $(\mathrm{UFN})$ は癌化, 癌細胞増殖, 宿主正常細胞の反応, 転移など様及 な過程との関連が示唆されている. 今回我々はこれらの過程のうち, 生体内における癌 細胞増殖とUFNとの関連を明らかにする目的で，マウスと交叉反応を示さないUFN測 定キットを用い, ヒト肺癌細胞担癌マウスのUFNを測定した。その結果, 非担癌マウ ス, 癌細胞移植後腫嗙形成前, 腫瘍形成後の 3 群間でUFNは有意に増加した. また腫瘍 形成後の腫瘍推定重量とUFNに相関がみられた. 病理学的に皮下腫瘍は癌細胞で構成さ れ, FN染色陽性であった。明らかな転移病巣はみられなかった。癌化や転移, 宿主反応 の影響を除外した生体モデルにおいてUFNが上昇したことより，腫瘍細胞に由来する FNが尿中へ排泄され，UFNとして測定されていることが強く示唆された.
\end{abstract}

〔肺癌 $34(3): 363 \sim 369$, 1994〕

Key words : Fibronectin (FN), Urinary fibronectin (UFN), Tumor marker

\section{はじめに}

フィブロネクチン $(\mathrm{FN})$ は血漿中や結合組織 などに広く分布している糖蛋白であり, 細胞形 態保持や組織修復などに関与している1). 癌患 者の尿中にはこのFN, とくに断片化したFNが 増加していることが示され²), 尿中FN(UFN) と癌との関連が検討されている. 教室の谷尾ら は臨床例において, 肺癌病期の進行に伴って UFNが上昇し，特に遠隔転移を伴った症例にお いて高値であることを報告した ${ }^{3)}$. しかし担癌 患者のUFNは癌細胞の増殖, 宿主正常細胞の反 応，転移など様々な過程が複雑に影響するもの と考えられ, 臨床において同一個体での癌増殖 過程におけるUFNの変動を, 経時的に評価する 事は不可能である。またこれまで各過程におけ

昭和大学外科学教室 る研究はin vitroによりなされており,生体内に おける腫瘍と尿中フィブロネクチンの関係に関 する報告はきわめて少ない。 今回我々は, 癌化 や転移, 宿主反応の影響を可及的に除外し, 生 体内における局所の癌細胞増殖とUFNとの関 係を明らかにする目的で以下の実験モデルを作 成した。すなわち，転移が希とされるヌードマ ウスにヒト肺癌細胞株を皮下移植し, ヌードマ ウスと交叉反応を示さないモノクローナル抗体 を用いて, ヒト癌細胞由来のUFN測定を行う事 により宿主反応の影響を除外, 腫瘍の増大過程 におけるUFNの変動を検討したので報告する。

\section{実験方法}

実験動物は, 生後 6 週令の雄BALB/c ヌード マウス $(\mathrm{nu} / \mathrm{nu})$ であり, 1 週間予備飼育後, 実験 
に供与した。

マウス皮下移植に用いたヒト肺癌細胞株は, 長期経代培養され移植生着の良好な PC-9, PC14 を選択し, 10\%FCSを含むRPMI-1640培地中 に, $37^{\circ} \mathrm{C}, 5 \% \mathrm{CO}_{2}$ の条件下で継代維持されてい るものを使用した。

方法は, ヌードマウス予備飼育後, 1 週間の 間に適時採尿 ( 1 回尿) し, コントロール(29尾, 132検体) とした. その後, 上記培養細胞 $5 \times 10^{6}$ 個を $0.2 \mathrm{ml}$ のPBS液に浮遊させ, $23 \mathrm{G}$ 針でマウ ス背部皮下に注入(PC-9：11尾, PC-14：12尾) した. 皮下移植後, 腫瘍を形成して直径 $5 \mathrm{~mm}$ 以 上となり，なお増大傾向を示したものを生着と 判断し，「腫瘍形成」とした. 腫瘍増大によって 背部表皮に糜爛を形成する直前まで可及的に採 尿(PC-9：8 尾, 64検体, PC-14：12尾, 44検体) および各採尿時の腫瘍径を測定し, UFNとの関 連を検討した。

各採尿ポイントにおける腫瘍推定重量は腫瘍 径をノギスで計測し, 長径 $(\mathrm{L})$ および短径 $(\mathrm{W})$ から $\mathrm{L} \times \mathrm{W}^{2} / 2$ の計算式より求めた. 形成された 腫瘍は一塊となるものが多かったが, しばしば $2 \sim 3$ 個の連続した数珠状の腫瘍を形成するも のもあり，その場合には各腫瘍径から求めた換 算腫瘍重量の総和とした。

なお，最長 4 力月にわたり非移植マウスの UFNを測定し, マウスの成長ならびに採尿時刻 に伴うUFNの変動がみられないこと( 9 尾，39 検体), また移植細胞浮遊液作製に使用した PBS液のみを $0.2 \mathrm{ml}$ 皮下注入した場合, その後 のUFNに変動がなく ( 2 尾, 19検体), 注入操作 やPBS液がUFNに影響を与えないことを予備 実験にて確認した。

UFN測定には, FN10, FN30の 2 種モノクロ 一ナル抗体によるワンステップ・サンドイッチ EIA 法によるUFN 測定キット“UFN 測定一 EIAキットTaKaRa”(ミズホメディー社) 4)を用 いて, 比色定量法により求めた。なお, FNはお よそ6 個 $(\mathrm{I} \sim \mathrm{VI})$ の機能と関連した特殊な構造 領域(ドメイン)から構成されるが，FN10なら びにFN30は,このうち細胞の結合部位である FN分子中央部の第 IVドメインを認識するもの
である1.すなわち本キットにより測定された $\mathrm{UFN}$ は, 断片化したFNも含めた総FN量を示 している5).

実験終了後は屠殺し, 形態学的検討のため腫 瘍・肝・脾・肺・腎の組織切片を作製し, HE染 色した. さらに腫瘍組織はヒストファイン SAB $-\mathrm{PO}(\mathrm{M})$ キット（株式会社ニチレイ）を用いて, 酵素抗体 Avidine - Biotin - Peroxidase Com$\operatorname{plex}(\mathrm{ABC})$ 法によりモノクローナル抗体 FN30 (Anti-Human Fibronectin FN30-8, 宝 酒造株式会社)を一次抗体としてFNを染色し た.

統計学的有意差検定にはWilcoxon検定を用 い, $\mathrm{p}<0.05$ を有意差ありと判定した。

\section{結 果}

腫瘍細胞皮下移植により, PC-9では11尾中 8 尾 (73\%)，PC-14では12尾全例 (100\%)に腫瘍形 成が認められた。腫瘍細胞皮下移植から腫瘍形 成と判断するまでの期間は, PC-9では 5 97日 (平均27日), $\mathrm{PC}-14$ では 4 14日 (平均 12 日) で あった.また, 腫瘍形成時点から実験終了(屠殺) までの期間はPC-9では26〜91日 (平均58日), PC-14では 4〜49日 (平均18日)であった。

I . UFNの分布 (Fig. 1)

コントロールは29尾より得られた132検体で, $\mathrm{UFN}$ の分布は $0 \sim 19.5 \mathrm{U} / \mathrm{mg}$.Cr. (平均 $\mathrm{S} \mathrm{SD}$ : $5.2 \pm 5.4 \mathrm{U} / \mathrm{mg}$.Cr.) であった (Fig. 1-A)。また, 細胞移植後腫瘍形成以前の UFN 分布はPC9 ( 9 尾, 52検体) $0 \sim 20.4 \mathrm{U} / \mathrm{mg}$.Cr. $(8.6 \pm 5.9 \mathrm{U}$ $/ \mathrm{mg}$.Cr.), PC-14 ( 2 尾, 4 検体) $7 \sim 16.4 \mathrm{U} / \mathrm{mg}$. Cr. (12.3土4.0U/mg.Cr.)であった (Fig. 1-B, D). さらに腫瘍形成後のUFN分布はPC-9(8 尾, 64 検体) $1.0 \sim 58.1 \mathrm{U} / \mathrm{mg}$.Cr. $(16.2 \pm 10.7 \mathrm{U} / \mathrm{mg}$. Cr.), PC-14 (12尾, 44検体) $0 \sim 82.8 \mathrm{U} / \mathrm{mg}$.Cr.

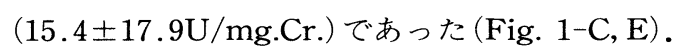
PC-9ではコントロールと細胞移植後腫瘍形 成前, コントロールと腫瘍形成後, さらに細胞 移植後腫瘍形成前と腫瘍形成後の各々に有意差 を認めた.また, PC-14ではコントロールと細胞 移植後腫瘍形成前, およびコントロールと腫瘍 形成後の間で有意差を認めた。 
Fig. 1. Correlation between UFN and tumor formation.

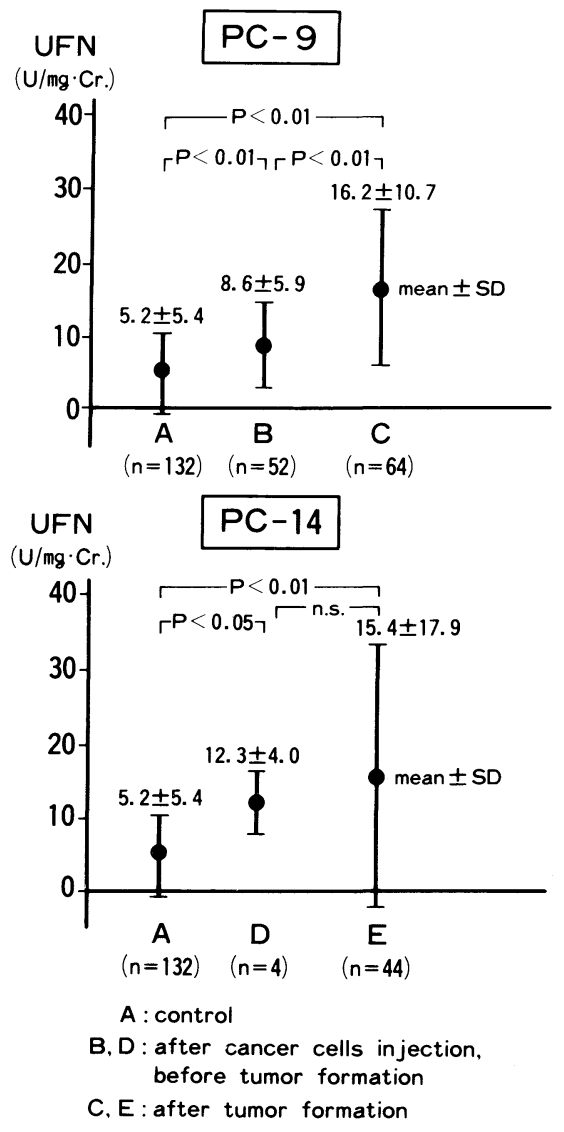

II. 換算腫瘍重量の分布とUFNとの関係 (Fig. 2)

腫瘍形成から実験終了までの, 各採尿時に測 定した換算腫瘍重量の分布は, PC-9(8 尾, 64検 体)では $63 \mathrm{mg} \sim 5.6 \mathrm{~g}$ (平均 $959 \mathrm{mg}$ ), $\mathrm{PC}-14(12$ 尾，44検体) では $63 \mathrm{mg} \sim 10 \mathrm{~g}$ (平均 $2384 \mathrm{mg}$ ) であ った，腫瘍形成後，採尿時に測定した換算腫瘍 重量と UFN との相関係数は, PC-9が $0.64(\mathrm{p}<$ 0.01)， PC-14が0.57( $\mathrm{p}<0.01)$ であった。

Fig. 3に換算腫瘍重量 $500 \mathrm{mg}$ 前・後における UFNの差を示した.PC-9腫瘍形成後の腫瘍重 量500mg未満におけるUFN平均值は $12.6 \pm 6.4$ $\mathrm{U} / \mathrm{mg}$.Cr., 500mg以上のそれは $20.0 \pm 12.9 \mathrm{U} /$ mg.Cr., PC-14腫瘍形成後の腫瘍重量500 $\mathrm{mg}$ 未

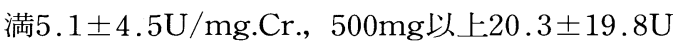
/mg.Cr.であった. PC-9では, コントロール, 腫 瘍重量 $500 \mathrm{mg}$ 未満, ならびに $500 \mathrm{mg}$ 以上の各々
Fig. 2. Correlation between UFN and tumor growth.
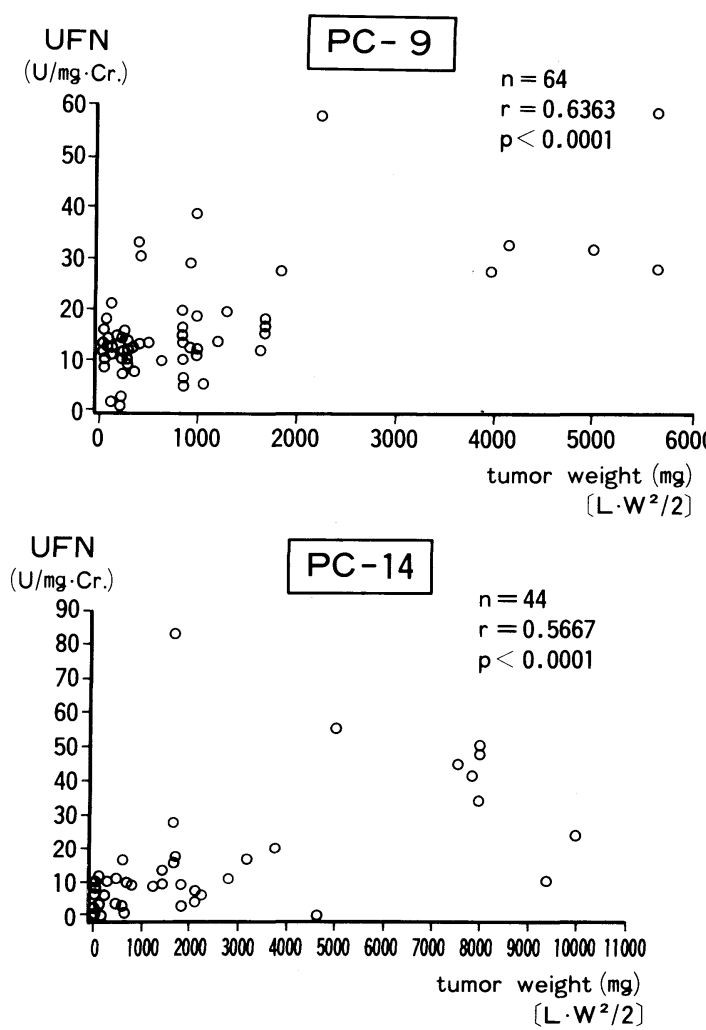

に有意差を認めたＰC-14ではコントロールと 腫瘍重量500mg未満との間に有意差はみられな かったが, コントロールと500mg以上,ならびに $500 \mathrm{mg}$ 未満と $500 \mathrm{mg}$ 以上のUFNに有意差を認 めた。

III. 病理組織標本 (Fig. 4 6)

皮下移植した腫瘍が糜爛を形成する直前で実 験終了としてマウスを屠殺解剖し, 組織学的検 討を加えた。生着, 増大した腫瘍は癌細胞で構 成され，主に圧排性増殖がみられたが，マウス 筋組織への浸潤様所見も認められた。炎症所見 は極めて軽度であった。

PC-9細胞移植によって形成された腫瘍 (Fig. 4A) は未分化な癌細胞であり, シート状充実性 増殖を示していた．部分的には管腔様構造を形 成し，また表皮近傍リンパ管への強い浸潤傾向 もみられた。腫瘍細胞は大きく, 核は偏在傾向 で腺癌様の分化傾向を示し, 一部に多核細胞を 
Fig. 3. Correlation between UFN and tumor weight.

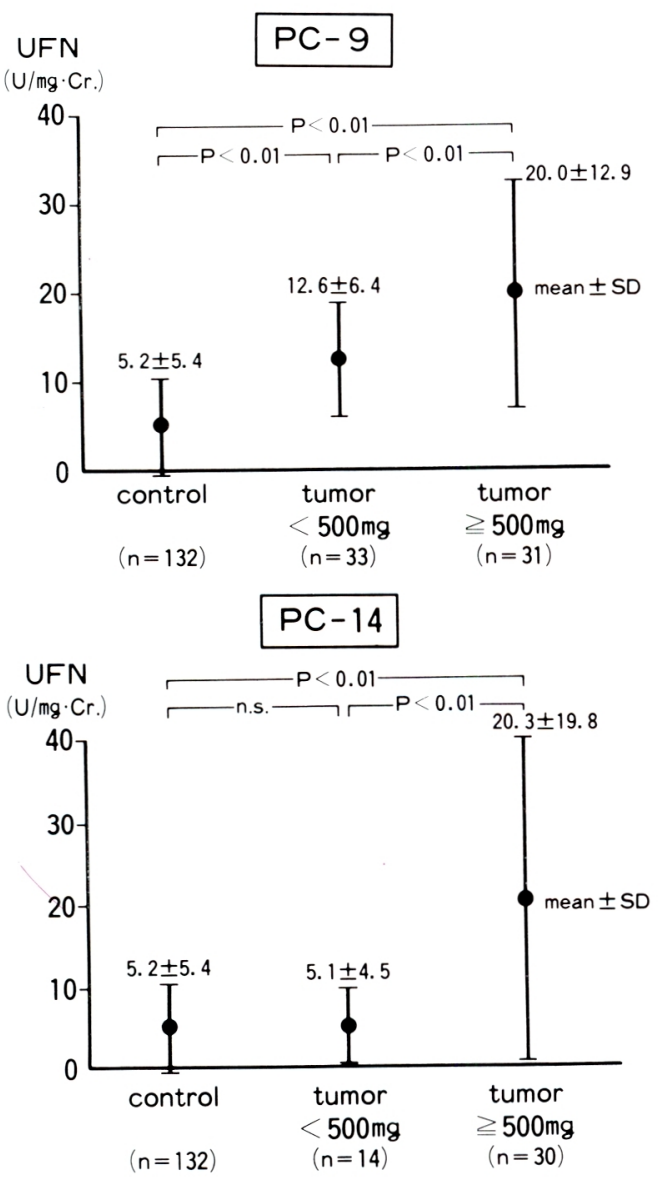

Fig. 5. Fibronectin staining of the tumor cells (PC-9, FN30).

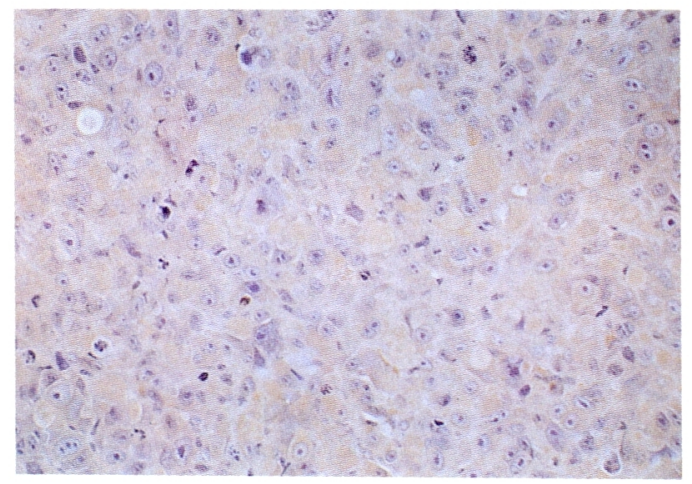

認めた。

一方PC-14の腫瘍細胞 (Fig. 4B) はPC-9細胞 と比較して小型で， $\mathrm{N} / \mathrm{C}$ 比が大きく, 核は偏在 傾向にあった。細胞密度は高く, 増殖能の激し いことを筧わせ，部分的にロゼット様構造を呈 していた。

$\mathrm{ABC}$ 法による腫瘍組織の染色では, 癌細胞は フィブロネクチン陽性であった (Fig. 5)。マウ 又皮下組織の染色所見は, 癌細胞非移植正常又 ウスでは染色されなかった(Fig. 6A)のに対し て，腫湯形成マウスでは様々な程度で染色され るものがあり, 癌細胞よりも強く染色されたマ ウスも存在した(Fig. 6B).

なお, ヌードマウス諸臓器への明らかな転移 は認めなかった。
Fig. 4. Tumor cells (H.E.). A) PC-9, B) PC-14.

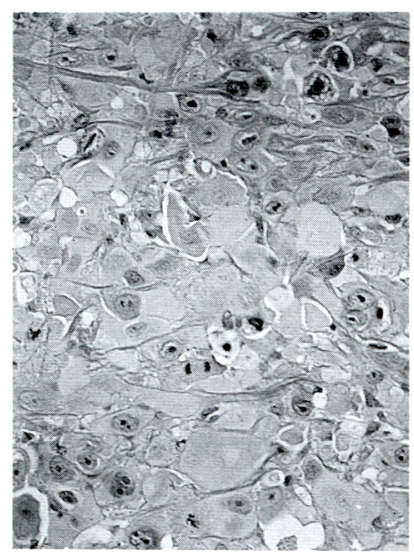

A)

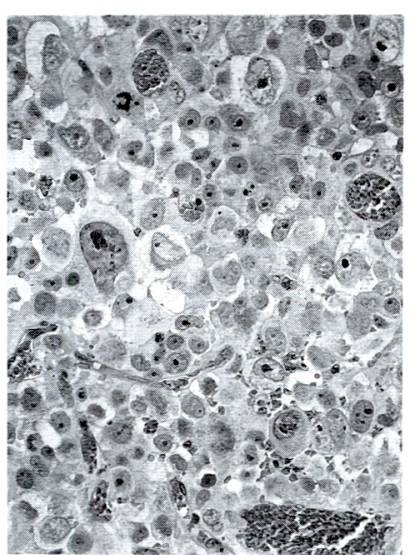

B)

\section{考 察}

フィブロネクチン $(\mathrm{FN})$ は細胞接着, 細胞伸展・移動・増殖, 食細胞, 組織 修復の促進, 細胞分裂の調節などの他 に, 癌細胞の浸潤転移の抑制に関与す るとされている1,6).

血漿 $\mathrm{FN}$ と癌との関係については, 癌患者の血漿FNが健常者よりも高值 を示し, このため血漿FNが腫痬マ一 カーとして期待されたが，血漿FNは 感染症, 外傷, 熱傷, 糖尿病, 妊娠, DIC, ショック, 敗血症, 飢餓状態など 
でも増減することから，腫瘍マーカーとしての 意義は少ないと考えられている7).

一方, 尿中 FN と癌との関係については, 前立 腺癌や消化器癌患者尿中にFNが増大し ${ }^{8), 9)}$, 血 漿FNに比べて, 低分子化していること年，癌の 病期進行に伴いUFNが増加することかが示され， UFNの腫痬マーカーとしての意義が検討され ている。

今回我々はヌードマウスを用いて腫瘍発育と UFNとの関係を中心に検討した結果, 癌細胞浮 遊液をヌードマウス皮下八注入後, 腫瘍生着に よってUFNは上昇した。さらに腫瘍生着後, そ の増大とともにUFNも上昇したが, 一方, 明ら かな転移巣はみられなかったことより，本実験 モデルにおいても, UFN上昇は局所腫演增殖に 関連していることが確認された。

なお, ヌードマウス由来のUFNとUFN測定 キットとの交叉反応に関しては, 同反応が存在 する場合にはヌードマウス血清FNがUFNの約 1000倍程度の值を示すとされている。しかし予 備実験では, マウス血清FNとUFN測定キット との反応はみられず,コントロール(腫瘍非移植 マウス)におけるUFN值 $5.2 \pm 5.4 \mathrm{U} / \mathrm{mg}$.Cr.は バックグランドによるものと考えられた。

担癌生体におけるUFNの由来については, 細 胞の癌化によって細胞表面からFNが激減する ことが示され11), その理由として, 細胞性FN産 生細胞における遺伝子の発現転写がなんらかの 原因で抑制されるためにFNが減少し, 細胞形 態の変化，細胞間粘着性の消失，細胞間共同作 用の抑制が起こり，癌化するものと考之られて いる6)。すなわち癌化過程においてはFN発現が 低下しているのに対して, 癌細胞增殖過程にお いては, 癌細胞や癌周囲結合組織による $\mathrm{FN}$ 産

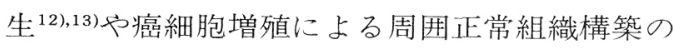
破壊, 癌細胞による $\mathrm{FN}$ 分解酵素産生 ${ }^{14)}$ に伴う FN断片化など, 局所FN産生, 破壞の克進が考 えられている.UFNが, 癌の病期進行に伴い増 加するのはこれらの機序が複雑に影響している ものと考之られる。本実験モデルはこれらの機 序のうち, 局所に扔ける癌細胞の増殖とUFNと の関係に着目し、ヌードマウスという宿主を用
Fig. 6. Fibronectin staining of subcutaneous tissue (FN30).
A) Mouse without tumor

B) Mouse with tumor
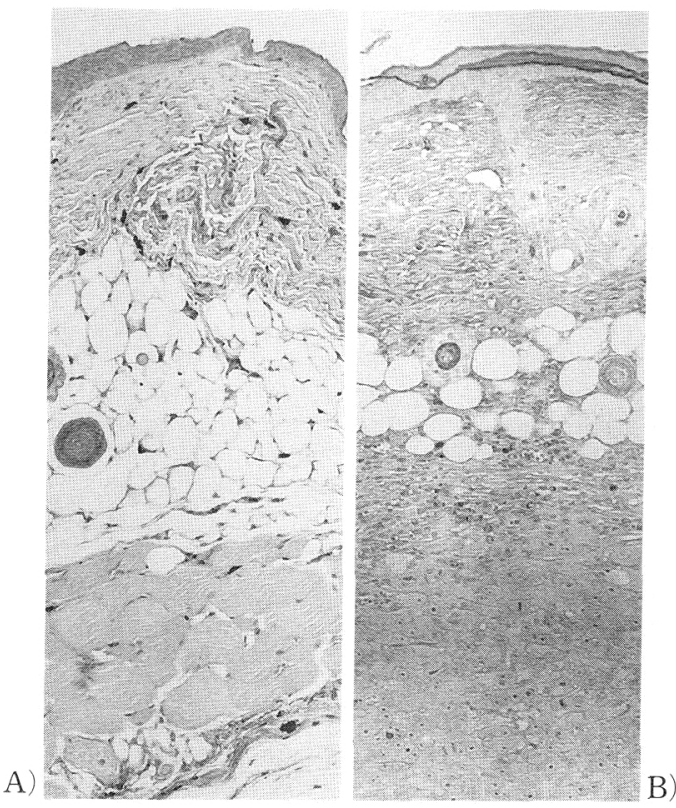

B)

いて, ヒト肺癌細胞と七卜由来UFNの関連を求 めたものである。癌化過程を除外する目的で, 癌細胞の異種生体内移植という手法を用いた結 果, 移植細胞の増殖によってUFNが増加してい る事から, 正常細胞の癌化か UFN上昇に不可欠 な条件ではないことを示した。また，本検討に 用いたUFN測定キットならびにFN染色キット がヌードマウスと交叉反応性を呈さないことか ら, 腫瘍増大に伴う周囲結合組織の破壊もUFN 上昇に必ずしも必要な事項ではないと考えられ た。さらにモノクローナル抗体を用いた腫瘍 組織染色でFN陽性であったことから，生体内 における癌細胞数の増加によりUFNが腫瘍径 にほぼ比例して上昇したものと思われた。マウ ス皮下組織が腫瘍移植マウスに扔いて様々な程 度で染色されたことは, 非移植マウスで染色さ れなかったことから，七卜腫瘍由来のFNがマ ウス皮下組織に沈着していることが推測された。 なお, 今回の実験結果は癌化過程や腫瘍周囲組 織の反忘とUFNとの関連を否定するものでは ない。 
今後は, 腫瘍組織から尿中排泄にいたる間の FN断片化や代謝分解経路について明らかにし たいと考えている。

\section{結 語}

ヌードマウス皮下に移植したヒト癌細胞の生 着・増大に伴い，尿中フィブロネクチン值 (UFN) も増加した. 腫瘍細胞由来のフィブロネ クチンが尿中へ排泄されることが示唆された。
稿を終えるにあたり，本研究に協力頂いた宝酒造株式 会社薬品研究所 片山政彦先生, 昭和大学医学部第一内 科学教室 堀地直也先生, 外科学教室研究室 西野信一氏 ならびに教室員諸兄, 動物管理室諸氏, “UFN測定-EIA キットTaKaRa”を提供頂いた宝酒造株式会社に深謝致 します.

なお，本論文の要旨は第33回日本肺癌学会総会 $(1992$ 年, 名古屋)において報告した。

\section{文 献}

1）出屋敷喜宏，鈴木宏治：フィブロネクチン．検 查と技術 $15: 996-1000,1987$.

2) Katayama M, Hino F, Kamihagi $K$, et al : Urinary fibronectin fragments (a potential tumor marker) measured by immunoenzymometric assay with domein-specific monoclonal antibodies. Clinical Chemistry 37 : 466-471, 1991.

3）谷尾 昇, 門倉光隆, 高場利博：原発性肺癌患 者における尿中フィブロネクチン断片(UFN) 測定の検討. 肺癌 $31: 207-214,1991$.

4）神谷憲太郎, 志賀俊行, 川内章裕, 他：“UFN 測定一EIAキットTaKaRa”による尿中フィブ ロネクチン断片 (UFN) 測定に関する基礎的検 討. 医学々薬学 $22: 621-626,1989$.

5）片山政彦, 日野文嗣, 加藤郁之進, 他：モノク ローナル抗体による癌患者尿中フィブロネク チン細胞接着部フラグメントの測定. 医学の歩 み $150: 695-696,1989$.

6）赤間高雄, 林 正男：フィブロネクチンの構造 と機能. 代謝 $23: 955-962,1986$.

7) Choate JJ, Moster DF : Fibronectin concentration in plasma of patients with breast cancer, colon cancer, and acute leukemia. Cancer 51 : 1142-1147, 1983.

8) Webb KS, Lin GH : Urinary fibronectin. Investigative Urology $17: 401-404,1980$.

9）竹内節夫, 高塚 純：転移と尿中フィブロネク チン. 最新医学 $41: 2275-2280,1986$.

10）高塚 純, 磯貝正博, 久保田和博, 他：“UFN 測定一EIAキットTaKaRa”による尿中フィブ ロネクチン断片 (UFN) 測定の検討. 医学と薬 学 $22: 633-639,1989$.

11) Hynes RO : Alteration of cell-surface proteins by viral transformation and by proteolysis. Proc Nat Acad Sci $70: 3170-$ 3174, 1973.

12) Alitaro K, Oja JK, Vaheri A : Extracellular matrix proteins characterize human tumor cell lines. Int J Cancer $27: 755-761,1981$.

13) Stenman $\mathrm{S}$, Vaheri A : Fibronectin in human solid tumors. Int $\mathrm{J}$ Cancer $27: 427-435$, 1981.

14) Chen JM, Chen WT : Fibronectin-degrading proteases from the membranes of transformed cells. Cell 48:193-203, 1987. 


\title{
Analysis of Urinary Fibronectin (UFN) using Human Lung Cancer Cells Transplanted into Nude Mice
}

\author{
Makoto Nonaka, Mitsutaka Kadokura, Noboru Tanio, \\ Shigeru Yamamoto and Toshihiro Takaba \\ Department of Surgery, Showa University School of Medicine
}

Fibronectin is widely distributed in the body, i.e. in plasma, on basement membrane and so on. Since great amounts of urinary fibronectin (UFN) are seen in patients with cancer, UFN is considered to be related with cancer growth and metastasis. In this study, we transplanted human lung cancer cells (PC-9, PC-14) into athymic nude mice subcutaneously, and measured both the concentration of UFN and tumor size of the mice periodically. We also analyzed the changes of UFN in relation to the growth of the tumor. As a result, the levels of UFN increased after cancer cell transplantation, and a correlation between tumor growth and UFN levels was observed statistically. Histopathologically, these subcutaneous tumors consisted of cancer cells, and they were positive for immunohistochemical staining with the $A B C$ method using anti-fibronectin monoclonal anti-body. No metastatic lesions were seen in the mice. We conclude that urinary fibronectin is derived from cancer cells and increases with the growth of the tumor. 